\title{
Higher education expansion, system transformation, and social inequality. Social origin effects on tertiary education attainment in Poland for birth cohorts 1960 to 1988
}

\author{
Katarzyna Kopycka ${ }^{1,2}$ (D) \\ Published online: 8 July 2020 \\ (C) The Author(s) 2020
}

\begin{abstract}
This paper analyzes the development of social inequality in the Polish higher education system during its expansion after 1990 using data from the Polish General Social Survey. Focusing on the special case of a former socialist society, where higher education expansion has been very rapid and achieved mainly through marketization, this paper highlights the micro-level mechanisms that underlie the inequality dynamic. It shows how actor preferences embedded in the specific historical context shape educational behavior, producing moments of equalization and de-equalization. Class inequality regarding access to tertiary education decreased in the early 1990s and then increased again, as participation in the working classes stagnated at a low level in the later phases of the expansion. In contrast, no equalization has been observed between children of different educational origins. The analysis shows a persistent intergenerational reproduction of educational disadvantage in spite of the expansion. Lastly, consistent with the Effectively Maintained Inequality thesis, this paper provides evidence for underprivileged strata being diverted into second-tier, lower-prestige educational opportunities in the private sector.
\end{abstract}

Keywords Higher education expansion · Poland - Transformation society · Social inequality · Diversion effect $\cdot$ Marketization

Electronic supplementary material The online version of this article (https://doi.org/10.1007/s10734-02000562-x) contains supplementary material, which is available to authorized users.

Katarzyna Kopycka

katarzyna.kopycka@soziologie.uni-halle.de

1 Institute of Economics, University of Łódź, Rewolucji 1905 r. 41/43, 90-214 Łódź, Poland

2 Institute of Sociology, University of Halle-Wittenberg, Emil-Abderhalden-Str. 26-27, 06108 Halle (Saale), Germany 


\section{Introduction}

Throughout the last three decades, the educational landscape of developed countries has changed much due to the processes of expansion in higher education. The pace and scope of these developments have varied across national contexts, but the trend can safely be regarded as universal (Schofer and Meyer 2005). Academia has addressed multiple reasons for this dynamic, ranging from parental educational strategies (Walters 2000; Marginson 2016) to enhancing regional competitiveness in a globalized knowledge economy (OECD 2007; Valero and Van Reenen 2019). Last but not least, scholars stress the social equity aspects. The expansion of education is seen as a chance to diminish educational inequality and increase social mobility by political means (Pinheiro and Antonowicz 2015; Beller and Hout 2006). In fact, the assurance of growing equity in access to higher education has been formulated as an explicit goal of European policy (London Communiqué 2007, Bucharest Communiqué 2012). As far as educational inequality is concerned, however, the alleged beneficial consequences of educational expansion for the equalization of educational opportunity still pose an open question. A body of empirical evidence shows persistent inequalities despite expansion (Shavit and Blossfeld 1993; Arum et al. 2007; Raftery and Hout 1993; Boliver 2011). Moreover, widening access to tertiary education is most often accompanied by processes of internal stratification, which result from processes of horizontal differentiation (Marginson 2016; Noelke et al. 2012; Ayalon and Shavit 2004; Lucas 2001; Czarnecki 2018; Duta et al. 2018).

Whereas most empirical evidence and theoretical frameworks regarding the consequences of higher education expansion for inequality come from the perspective of high-income Western countries, this paper advances the state of research by focusing on Poland, a former socialist country in Eastern Europe. It thus offers an opportunity to reflect upon the existing theoretical body from a different socio-historical context and to highlight the underlying micro-level mechanisms that drive inequality in expanding higher education systems. In this respect, the analysis clearly shows the importance of preferences embedded in status attainment strategies of different social origin groups, which are context- and time-specific.

There are three distinctive features of higher education expansion in Poland that make this case especially interesting. First, the pace of the expansion process there has been very high. The absolute number of students increased almost fivefold from 1991 to 2006 . So far, only a few studies have addressed this issue with respect to inequality, even though the rate of expansion is increasing worldwide and is especially strong in developing countries (Marginson 2016). I argue that a high pace of expansion may exacerbate educational inequality at the beginning, reflecting a slower behavioral adaptation to new opportunities among less privileged groups.

Second, higher education expansion in Poland has been accompanied by a broad marketization of the sector (Kwiek 2011, 2009). There is a worldwide trend towards marketization, as it enables educational expansion despite state budgetary constraints, and it is, therefore, especially relevant in developing countries (Altbach et al. 2009). It was important for East Asian countries and in Latin America. Still, whereas increasing the supply of higher education may decrease inequality in access (Arum et al. 2007), private mass higher education is often of lesser quality (Welch 2007; Marginson 2016), and as such may constitute a stratifying moment to the system, reproducing social inequality (Schendel and McCowan 2016). This paper provides evidence of such a stratifying dynamic in Poland. 
Third, educational expansion unfolded in Poland under the exceptional conditions of the country transforming to a market economy, which involved a re-valuation of different forms of capital and channels for social mobility. This period witnessed rapidly growing labor market returns to formal education (Nee 1989; Domański 2011), but also the emergence of a new class of large and medium-large entrepreneurs making their fortunes at the time of the large-scale privatization of state enterprises. I argue that this specific historical context may have shaped the educational preferences of various social strata differently, producing equalizing moments, and challenging the established theory.

\section{Links between inequality and expansion}

Raftery and Hout (1993) proposed a theoretical link between educational expansion and inequality in educational attainment, labeling it Maximally Maintained Inequality (MMI). According to this thesis, new attractive educational opportunities that emerge in the process of educational expansion will be disproportionately absorbed by the privileged middle class, thus leading to the persistence of class differences in educational attainment. Raftery and Hout offer a rational choice explanation for such a pattern involving two mechanisms. First, higher social class backgrounds attach greater utility to educational achievement; second, the cost of education is relatively lower for more affluent families due to the concavity of the utility function. Together, they form a structural disadvantage of lower-class backgrounds in access to education, which results in persistent inequality. Only when higher social classes reach the state of saturation at a given educational level will sustained educational expansion lead to decreasing educational inequality until a given level of schooling becomes universal. In accordance with this argument, I expect that distances will decrease between social origin groups in their chance of entering higher education only after the privileged groups have reached saturation with higher education (the MMI hypothesis).

MMI has been criticized for its disregard for internal differentiation and tracking as an important vehicle of educational inequality. Horizontal differentiation and internal stratification have appeared in reaction to growing attainment rates at a given level of education (Trow 1970; Bloch and Mitterle 2017). Quantitative differences, in the form of more or less education, are being replaced by qualitative differences in the type of study program, field of study, or educational institution. This argument was summarized by Lucas (2001) in the thesis of Effectively Maintained Inequality (EMI). According to Lucas, students of lower socio-economic backgrounds are disproportionately more often found in lower-prestige, lower-quality, and less-selective educational institutions or programs, which offer lower occupational returns. Such a diversion may be especially strong in systems that select on merit, as high cultural capital increases school performance (DiMaggio 1982). For the subsequent analysis, I expect that students of lower social origin will bear a higher risk of being enrolled in second-tier higher education opportunities (diversion hypothesis).

One possible source of internal differentiation is the marketization of higher education. According to Arum et al. (2007), educational systems in which funding from private sources plays a significant role exhibit higher participation rates, but they are also more internally stratified, typically with exclusive status-seeking, first-tier institutions, and an inclusive clientseeking, second-tier segment. In systems where expansion has been mainly driven by private funding, its effect on educational inequality is principally indeterminate. On the one hand, a higher participation level may generate saturation in higher classes and decrease ability 
requirements, thus leading to decreasing social origin effects in attainment. For example, Ayalon and Mcdossi (2019) have recently shown that, for Israel, privately financed higher education opportunities provide an effective channel to graduation in lucrative study fields for wealthy children of nonacademic backgrounds. On the other hand, market-based systems rely on tuition fees, a condition that may hinder lower classes from taking advantage of educational opportunities because of financial constraints. Higher educational attainment in such systems would, therefore, more strongly rely on economic than educational capital. For Poland, I expect social class background to be a stronger predictor of enrolment chances than parental education (the expansion via marketization hypothesis).

Last but not least, no attention has been paid to the pace of the expansion process within the frameworks of MMI or EMI. It is possible, however, that the speed of change in the educational landscape may influence the strength of relative disadvantage in access among underprivileged social groups and its temporal dynamic. On the one hand, as proposed by Blossfeld et al. (2017), the rapid growth in educational opportunity should decrease the level of inequality because the desired good is less scarce; hence, there is less conflict over its distribution. However, the authors report inconsistent results. Most importantly, despite high rates of higher education expansion in post-socialist countries, they find rising, not declining social origin effects on attainment there. On the other hand, rapid growth in tertiary education opportunities may increase the importance of informational deficits and behavioral adaptation as factors driving inequality. Where educational opportunities expand very fast, the difference in accessibility between social strata may be more pronounced, because time is needed for families of lower social background to adjust their educational behavior. Accordingly, one could expect to see persistent inequality in educational attainment even after the saturation level among privileged classes is reached. In such a scenario, the expansion at the tertiary level would simply come to a halt. Thus, I assume chances for enrolment in tertiary education of lower social origin groups to stay low even after higher social strata have reached the highest enrolment rates (the adaptational lag hypothesis).

So far, both the MMI and EMI theses have been only rudimentarily tested in the context of transition societies. Most notably, state socialist countries do not fit MMI well, as countries displaying high enrollment rates in post-secondary education (like Russia), as well as countries with low participation at the post-secondary level (like the former GDR), display low social origin effects on educational achievement (Hout 2007). MMI seems, therefore, particularly suited to inform research in democratic countries with a market economy. It is an open question, however, if expansion during a system change from state socialism to capitalism will result in a societal dynamic as described by MMI. Wu (2010) finds growing social inequalities in access to upper secondary education in China following educational expansion there. Kogan et al. (2012), analyzing cross-sectional data for a number of post-socialist European societies, report strong social origin effects at the secondary and tertiary education level regarding the choice of educational tracks. Blossfeld et al. (2017) find that the expansion of higher education in post-socialist countries has increased inequality in access to educational opportunities. Growing social inequalities have also been reported for Russia (Konstantinovskiy 2017).

For Poland, the current state of research on inequality in access to higher education is mixed due to the different methodologies and data used. On the one hand, Kwiek (2009) describes Poland as a "success story" in terms of its ability to raise the overall level of education in society despite severe budgetary constraints in the first phase of its transformation. Similarly, Wasielewski (2015) finds growing chances for rural youth to achieve tertiary education in the 
course of the educational expansion. In contrast, Domański (2008) reports growing inequality in educational attainment in Poland between 1982 and 2006. Similarly, Kwiek (2015) sees Poland among the four least-fluid European countries (together with Italy, Ireland, and Portugal) regarding the intergenerational transmission of tertiary education status. A recent analysis by Herbst and Rok (2014) provides a differentiated picture. Educational reproduction has fallen substantially in the course of higher education expansion. At the same time, inequality concerning family income has followed a u-shaped pattern. Using canonical correlation analysis, Sawiński (2018) finds stable social origin effects on the transition to university after completing secondary education in Poland after 1989 compared with the socialist period. Regarding inequality within tertiary education, Herbst and Rok (2014) provide cross-sectional evidence for a substantial diversion of lower educational background students into less prestigious, tuition-fee-based, and part-time study programs in the year 2008.

In order to provide background information on the specific case under study, the next section describes the development within Poland's tertiary education sector with special attention to the quantitative growth and privatization of higher education. I also sketch a wider social context in which the process of expansion took place, that is, in a society simultaneously undergoing a major transformation from state socialism to capitalism. Section four describes the data and methodology. Section five presents the results, and section six concludes.

\section{The expansion of higher education: The Polish case}

The structure of the Polish higher education system is organized hierarchically in three autonomous educational cycles of bachelor's, master's, and doctorate studies, thus complying with the framework of the European Higher Education Area. A small portion of academic study programs still offers tuition in an integrated long cycle granting a master's degree. The majority of students attaining a bachelor's degree continue their education at the master's level (Zajacc et al. 2017) because the bachelor's degree is still regarded as incomplete higher education (Piróg 2013) and attributed with lower social prestige (Kwiek 2014). A major feature of the system, which distinguishes it from other post-socialist countries, is its high proportion of private capital, both on the supply and on the demand side, which has been the main driving force of expansion from the early 1990s onwards.

Higher education in Poland under state socialism was a small unitary system of public universities that served not more than $10 \%$ of the student population. Access to higher education was predominantly based on academic ability, tested in university-internal admission examinations. The working classes enjoyed some degree of preferential treatment, which became relevant around the admission threshold. Despite the socialist equity ideology, access to higher education was largely limited to children of university-educated parents (the intelligentsia) (Kwiek 2009). The early 1990s saw an upsurge in demand for higher education, which could not be accommodated within public higher education institutions (Kwiek 2018). In the first two decades of the transformation to a market economy, wage premiums from tertiary level credentials sharply increased (Domański 2011), and higher education was regarded as giving protection from the risk of unemployment (Jeruszka 2011), which increased interest in studying among the youth.

The early liberalization of the legislation in higher education (in 1990 and again in 1997) facilitated a rapid growth in privately funded higher education opportunities - at newly created private higher education institutions or as tuition-fee-based part-time studies at public universities. 
The predominantly client-seeking institutions have lower or no admission criteria besides a secondary school diploma, and they pose an alternative for those who fail in the competition for admission to free studies at public universities. However, the quality of tuition in privately financed study programs is considered to be lower than in full-time programs at public universities. They lack prestige and social legitimacy (Jablecka 2007; Antonowicz et al. 2017), and offer significantly lower labor market returns (Długosz 2013). A result of the marketization has therefore been the emergence of second-tier, demand-absorbing higher education opportunities, which supplement a free-ofcharge but selective offer at public universities. A major share of the quantitative growth in the tertiary sector, but also a recent decline, is attributable to the development of the second tier. Figure 1 summarizes the key statistics on higher education in Poland over time, and marks the cohorts of the study (see Data and methodology section below).

In the socialist period, the number of students varied little, mainly reflecting the variation in cohort sizes. Throughout the last decade of communist rule in Poland, the net participation rate in higher education increased by two percentage points (from 7.5 to $9.5 \%$ ). Starting in 1990, the absolute number of students rose rapidly due to rising propensity for higher education but also due to growing cohort numbers. The year 2006 witnessed the highest number of students - nearly two million. The net participation rate in this period quadrupled, from less than $10 \%$ to $41 \%$ in the peak year of 2009. Much of this expansion was achieved through marketization, both in the form of private provision and private funding (Kwiek 2009). The number of students in private higher education institutions rose until 2008, when it reached $34 \%$ of the whole student population. It is important to note that private providers outnumber public ones. In the peak year of 2010 , there were 330 private higher education institutions, which comprised $72 \%$ of the total. Hence, private providers are multiple but small. The percentage of students paying tuition fees, which also contains part-time students at public universities, was $63 \%$, the highest in 2000, decreasing afterward, although it remained at a high level throughout the following decade.

The 2010s witnessed a significant drop in the number of students at private higher education institutions and in the percentage of fee-paying students. This development is mainly demographically driven. With decreasing cohort sizes, the competition over free-of-charge study places at public universities (which also expanded in the meantime) declines and the secondary, demand-

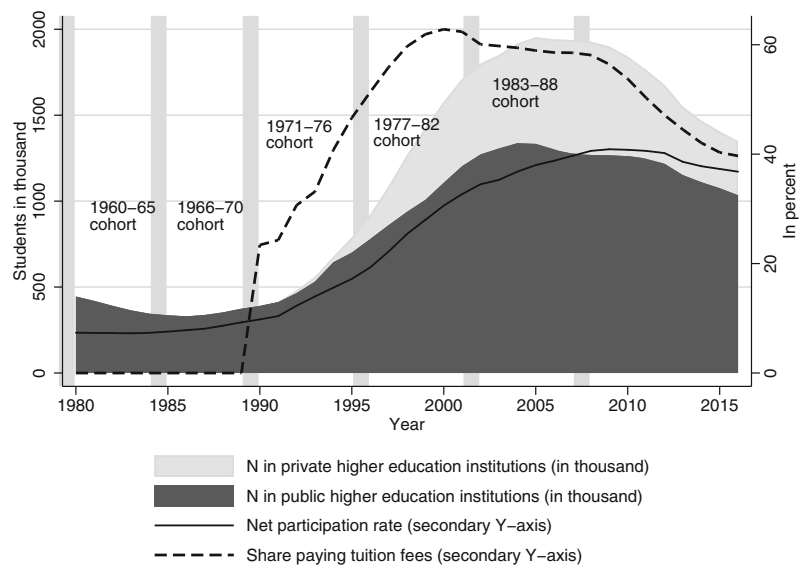

Fig. 1 Development of the higher education sector in Poland, 1980-2016. Gray bars mark cohorts covered in the empirical analysis (see Data and methodology). Source: (GUS 1981-2016) 
driven higher education sector contracts (Kwiek 2016). Moreover, the 2010s witnessed a slight decline in the net participation rate - to $37 \%$ in 2016, which may be attributed to declining relative returns from higher education from the mid-2000s (Myck and Najsztub 2016) and growing unemployment rates among higher education graduates (Jeruszka 2011).

The quantitative expansion in the higher education sector in Poland, quite exceptional regarding its pace, came about at a time of rapid economic transformation from state socialism to capitalism. On the one hand, this process resulted in rising premiums to higher educational levels, which is congruent with the modernization theory and the market transition theory (Nee 1989). A rise in the market value of higher education was established for Poland (Domański 2011), thus increasing the desirability of higher educational attainment.

On the other hand, the early transformation years also witnessed the emergence of a new business class, while access to this class was greatly facilitated by the social position held prior to the transformation, but not necessarily by the level of formal education. Those holding the top or near-top positions in the state socialist social hierarchy (the nomenklatura) had access to monetary resources, political power, and social networks. They also had relevant information that was crucial in promoting successful business activities, which flourished in the gray zone between the state and the private sector (Staniszkis 1990; Nee and Cao 2002). Słomczyński and Shabad (1996) established that, at the beginning of the transformation in Poland, social mobility into the business class was highest in the groups of top and middle managers and experts, that is, the top positions in the state socialist occupational hierarchy. Mach and Słomczyński showed by means of a logistic regression that holding a middle managerial position (which they define as being in charge of at least 25 subordinates, or of subordinates having subordinates themselves) and higher reported income prior to the transformation, but not educational level, significantly increased the odds of becoming a businessman (cited after Słomczyński and Shabad 1996). It can be argued that resources relevant for successfully running a business and connected to being a member of the nomenklatura could also be effectively transmitted intergenerationally, thus influencing the class reproduction strategies in this most privileged class.

\section{Data and methodology}

The analysis was conducted on data from the Polish General Social Survey (Cichomski et al. 2013; Cichomski and Sawiński 1995). The PGSS is a repeated cross-sectional individual survey with a wide array of questions in various socially relevant fields. Each wave of the study is a representative sample of Polish adult society with a multistage sampling design. Post-stratification weights are provided with the dataset. I use pooled data on individuals born from 1960 to 1988 from the PGSS waves from 1997 to 2010 (the last wave of the study).

In order to test for the hypotheses addressed in the introductory section, I estimate a series of logistic regression models with three hypothesis-specific dependent variables: (1) enrollment in a higher education institution, (2) paying a tuition fee, and (3) obtaining a master's vs. a bachelor's degree. The first one refers to the quantitative dimension of educational inequality, while the second and the third measure the degree of diversion in the higher education sector. ${ }^{1}$ The right-hand side of the equations includes variables that capture temporal variance

\footnotetext{
${ }^{1}$ Another interesting dimension of internal stratification of the higher education sector is studying abroad. The PGSS dataset does not contain this information, though.
} 
which reflects the educational expansion; two alternative explanatory variables pertaining to different dimensions of social origin (following Bukodi and Goldthorpe 2012): (1) father's social class, and (2) father's educational level; and a number of controls. I decided to operationalize social origin using the educational and class position of the father rather than the mother because the generally lower employment rates of mothers would result in more missing class data for them. Additional analysis with an alternative specification of parental education that takes into account the mother's educational attainment leads to similar results as the models with the father's education reported in the Results section; they are presented in the Online-Appendix (Fig. A1 and Table A1).

My reference category for social origin variables is always the highest class or educational level. It is a common practice in studies on educational inequality because it allows for the assessment of the distance of less advantageous backgrounds to the common benchmark of the most privileged group. For each combination of dependent and social origin variables, I specify a constant origin-education association model (Model 1) and a model allowing for temporal variation in this association by introducing interaction terms between time parameters and social origin variables (Model 2 ). In the face of concerns regarding the possibility of interpreting interaction effects in a logistic regression model in a substantive way, recently popularized by Mood (2010), I also estimate linear probability models as a robustness check. These alternative specifications are highly consistent with respect to effect patterns with the results of logistic estimations (Figs. A2-A7 in the Online-Appendix).

The expansion process in higher education is conceptualized in two ways. For enrollment and tuition fee, I use the method of cohort comparison most widely adopted in the field. In the models for enrollment, I differentiate five cohorts. The first (socialist) cohort, comprising birth years 1960 to 1965, reached eligibility for enrollment at a higher education institution between 1979 and 1984, and it provides a benchmark for inequalities in higher education before expansion. The second (transition) cohort was born between 1966 and 1970, thus reaching their higher education eligibility age in the years 1985-1989. This cohort may have responded to emerging new opportunities after 1989 and taken up studies belatedly because they were still relatively young at that time. The third cohort was born from 1971 to 1976 and represents the first stage of expansion in the higher education sector, which was characterized by a share of private higher education institutions that was still small. The fourth cohort consists of people born from 1977 to 1982 and represents the heyday of the expansion with a rapidly increasing proportion of private providers. Towards the end of the higher education entry period of the fifth cohort (comprising individuals born between 1983 and 1988), the expansion dynamic weakens, whereas the share of students enrolled in private institutions is at its peak. In the models concerned with paying for tuition, I drop the first and the second cohorts, because there were no tuition-fee-based study opportunities in the socialist period.

For the estimation of the chances of graduating with an MA, I confine my analysis to the 1971-1983 birth cohorts because, in order to be able to discriminate the type of attainment, the sample had to finish their education. I set the cut-point at 27 years, which is 3 years after the regular age of finishing with a master's degree, in order to reduce a possible bias towards the lower attainment level in younger cohorts due to non-completion at the time of the survey. Restricting the sample to individuals not younger than 27 means that the last cohort with available information is 1983 . 
Because the time horizon is essentially only 12 years, instead of cohort effects, I estimate a linear time trend (see, for example, Boliver 2011). In fact, participation rates in higher education in Poland grow almost linearly from 1990 to 2002, at which time the speed of the process decreases. The decrease coincides with the last couple of birth years of my sample, so forcing linearity to the data can be considered of minor relevance.

Parental social class was obtained by transforming the ISCO codes of the father's occupation at the respondent's age of 14 into a ten-category EGP class scheme (Erikson et al. 1979) using the isko package in Stata (Hendrickx 2002). It was subsequently recoded into four categories: (1) upper service class (as is, comprising owners of large companies, higher-level managers and administrators, and higher professionals), (2) lower service class (as is, i.e., lower-grade professionals, managers, and administrators, higher-grade technicians and supervisors of non-manual workers), (3) entrepreneurs (small proprietors with and without employees taken together), and (4) working class (a broad category combining manual supervisors, skilled and unskilled manual workers, and farmers, as well as a very small group of routine non-manual workers). The EGP scheme is currently the most widely used class scheme in European stratification research (Breen 2004). Previous studies have shown that the EGP classes depict social stratification in Poland quite well and do not differ from national classifications in their predictive power (Domański and Przybysz 2003). The parental education variable was recoded into four categories: (1) tertiary, (2) upper secondary and postsecondary non-tertiary, (3) lower secondary vocational, and (4) elementary and less than elementary education.

All estimated models control for typical regressors of enrolment in higher education (Rahona López 2009; Duta et al. 2018; Hanushek 1992; European Commission 2018) that are here of secondary interest: gender, the number of siblings, and the place of residence coded as a dummy variable representing the rural-urban divide. ${ }^{2}$ Moreover, I apply dummies for survey waves in the pooled dataset (all not reported in the coefficient tables, available from the author on request). The analysis was conducted on weighted data.

The estimation samples differ regarding which dependent variable is analyzed. For the enrollment and tuition-fee models, the sample comprises the waves 1997 to 2010 and individuals 20 years old or older at the time of the survey. The sample sizes are 1678 and 1750 for enrolment, and 657 and 691 for tuition-fee, for models with parental social class and education, respectively. Letting the estimation sample start with 20 -year-olds makes it possible to extend the analysis onto younger cohorts offering a longer observation window. However, it introduces a potential bias, because belated enrollment of the older cohorts can be observed in the data to a greater extent than that of the younger cohorts.

For the differentiation of bachelor's versus master's degree attainment, the data is confined to the 2002 to 2010 waves, because the earlier version of the educational scale did not discriminate between these two credentials, and to individuals aged 27 and older. This significantly limits the sample size to 247 for social class and to 255 for education. Table 1 presents descriptive statistics of the variables and sample sizes of the estimated models.

\footnotetext{
${ }^{2}$ Of separate interest is, if patterns of social inequality in access to tertiary education develop differently in rural and urban populations. Whereas a differentiation with respect to class of origin is less informative because of a strong bias towards the working class, I have obtained predictions of participation chances for various educational backgrounds in the population of rural youth. The results (presented in Online-Appendix, Fig. A8) are very consistent with the estimates for the aggregate population and supportive for the Maximally Maintained Inequality argument.
} 
Table 1 Descriptive statistics of samples for each model

\begin{tabular}{|c|c|c|c|c|c|c|}
\hline & \multicolumn{2}{|l|}{ Enrollment } & \multicolumn{2}{|l|}{ Tuition fee } & \multicolumn{2}{|c|}{ Master's degree } \\
\hline & $\begin{array}{l}\text { Social class } \\
\%\end{array}$ & $\begin{array}{l}\text { Education } \\
\%\end{array}$ & $\begin{array}{l}\text { Social class } \\
\%\end{array}$ & $\begin{array}{l}\text { Education } \\
\%\end{array}$ & $\begin{array}{l}\text { Social class } \\
\%\end{array}$ & $\begin{array}{l}\text { Education } \\
\%\end{array}$ \\
\hline \multicolumn{7}{|l|}{ Social class of origin } \\
\hline Upper service class & 13.99 & & 19.33 & & 19.84 & \\
\hline Lower service class & 13.30 & & 18.11 & & 22.27 & \\
\hline Entrepreneurs & 7.22 & & 10.81 & & 6.88 & \\
\hline Working class & 65.50 & & 51.75 & & 51.01 & \\
\hline \multicolumn{7}{|c|}{ Father's education level } \\
\hline Tertiary & & 11.02 & & 17.8 & & 20 \\
\hline Upper secondary & & 29.25 & & 40.81 & & 40 \\
\hline Lower secondary & & 37.75 & & 34.15 & & 30.20 \\
\hline Elementary & & 21.98 & & 7.24 & & 9.80 \\
\hline Enrolled in HEI & 46.27 & 46.63 & & & & \\
\hline Tuition fee & & & 49.01 & 49.64 & & \\
\hline Master's degree & & & & & 78.54 & 79.22 \\
\hline \multicolumn{7}{|l|}{ Birth cohort } \\
\hline $1960-65$ & 25.26 & 24.93 & & & & \\
\hline $1966-70$ & 17.05 & 16.90 & & & & \\
\hline $1971-76$ & 26.20 & 26.12 & 39.88 & 39.07 & & \\
\hline $1977-82$ & 21.11 & 21.42 & 39.27 & 39.65 & & \\
\hline $1983-88$ & 10.38 & 10.64 & 20.85 & 21.27 & & \\
\hline $\mathrm{N}$ & 2023 & 2106 & 657 & 691 & 247 & 255 \\
\hline
\end{tabular}

\section{Results}

\section{Inequality in access to higher education}

According to the MMI hypothesis, because the rate of growth in participation rates is higher than shifts in the distribution of social background characteristics, I expect to find rising participation levels across all social origin groups. At the same time, these group-specific increases are such that the relative odds of participating in higher education between the most privileged social background and other backgrounds remain constant until the privileged groups have reached saturation. ${ }^{3}$

Table 2 summarizes the results of a binary logistic regression of participation in higher education. Firstly, we can see that in the mean view of all cohorts under investigation (Models \#1), there is both a considerable social class as well as parental education gradient on the probability of being enrolled in a higher education institution. The odds for those with entrepreneurial and working-class backgrounds are only 38 and $26 \%$ of the odds of children of the upper service class, respectively (Table 2, column 1). Coming from a family with upper secondary education decreases the odds of participating in higher education to $45 \%$ of the reference group with a tertiary-educated father. Having a father with only lower secondary or elementary education reduces the odds by a factor of 0.16 and 0.11 , respectively (Table 2, column 3). A look at the model fit statistics reveals that the educational dimension of social origin has more explanatory

\footnotetext{
${ }^{3}$ I follow the research practice and speak of saturation with higher education in a given social background when the enrollment rate reaches $80 \%$ (Hout 2006; Arum et al. 2007).
} 
Table 2 Estimates of binary logistic regressions. Odds ratios

\begin{tabular}{|c|c|c|c|c|c|c|c|c|}
\hline & \multicolumn{4}{|l|}{ Class } & \multicolumn{4}{|c|}{ Education } \\
\hline & \multicolumn{2}{|l|}{ Model 1} & \multicolumn{2}{|l|}{ Model 2} & \multicolumn{2}{|l|}{ Model 1} & \multicolumn{2}{|l|}{ Model 2} \\
\hline & \multicolumn{2}{|l|}{ (1) } & \multicolumn{2}{|l|}{ (2) } & \multicolumn{2}{|l|}{ (3) } & \multicolumn{2}{|l|}{ (4) } \\
\hline & OR & s.e. & OR & s.e. & OR & s.e. & OR & s.e. \\
\hline \multicolumn{9}{|l|}{ Cohort (ref. 1960-65) } \\
\hline $1966-70$ & $1.62 * *$ & 0.27 & 1.59 & 0.68 & $1.41 *$ & 0.24 & 0.97 & 0.51 \\
\hline $1971-76$ & $2.56^{* * * *}$ & 0.39 & 1.66 & 0.63 & $2.15 * * *$ & 0.32 & 2.28 & 1.12 \\
\hline $1977-82$ & $3.25 * * *$ & 0.51 & $3.60 * *$ & 1.62 & $2.76^{* * *} *$ & 0.43 & $3.13 *$ & 1.66 \\
\hline $1983-88$ & $4.01 * * *$ & 0.80 & $4.42 *$ & 2.99 & $3.59 * * *$ & 0.70 & 7.77 & 8.19 \\
\hline \multicolumn{9}{|c|}{ Parental social class/ education (ref. upper service class/ tertiary) } \\
\hline Lower service class/Upper secondary (II) & $0.62 *$ & 0.12 & $0.36^{*}$ & 0.14 & $0.45 * * *$ & 0.09 & 0.51 & 0.20 \\
\hline $\begin{array}{l}\text { Entrepreneurs/ Lower secondary vocational } \\
\text { (III) }\end{array}$ & $0.38 * * *$ & 0.09 & $0.31 *$ & 0.18 & $0.16^{* * *}$ & 0.03 & $0.12 * * *$ & 0.05 \\
\hline Working class/ Elementary (IV) & $0.26 * * *$ & 0.04 & $0.25 * * *$ & 0.08 & $0.11 * * *$ & 0.03 & $0.12 * * *$ & 0.05 \\
\hline \multicolumn{9}{|l|}{ Interaction terms class/ education $\mathrm{x}$ cohort } \\
\hline II x 1966-70 & & & 1.06 & 0.65 & & & 1.23 & 0.74 \\
\hline II x 1971-76 & & & $3.30 *$ & 1.83 & & & 0.59 & 0.33 \\
\hline II x 1977-82 & & & 2.01 & 1.24 & & & 0.81 & 0.48 \\
\hline II x $1983-88$ & & & 1.74 & 1.60 & & & 0.73 & 0.82 \\
\hline III x 1966-70 & & & 0.99 & 0.85 & & & 1.86 & 1.12 \\
\hline III x 1971-76 & & & 0.98 & 0.73 & & & 1.36 & 0.76 \\
\hline III x 1977-82 & & & 1.04 & 0.80 & & & 1.22 & 0.72 \\
\hline III x 1983-88 & & & 3.09 & 3.08 & & & 0.56 & 0.61 \\
\hline IV x 1966-70 & & & 1.04 & 0.49 & & & 1.78 & 1.09 \\
\hline IV x 1971-76 & & & 1.51 & 0.63 & & & 1.11 & 0.65 \\
\hline IV x 1977-82 & & & 0.74 & 0.36 & & & 0.54 & 0.35 \\
\hline IV x 1983-88 & & & 0.69 & 0.48 & & & 0.11 & 0.14 \\
\hline Baseline odds & 0.87 & 0.29 & 0.98 & 0.38 & 0.95 & 0.33 & 0.89 & 0.40 \\
\hline $\mathrm{N}$ & 2023 & & 2023 & & 2106 & & 2106 & \\
\hline McFadden's Pseudo- $\mathrm{R}^{2}$ & 0.11 & & 0.12 & & 0.14 & & 0.15 & \\
\hline
\end{tabular}

$*$ for $\mathrm{p}<.05, * *$ for $\mathrm{p}<.01$, and $* * *$ for $\mathrm{p}<.001$

The models control for gender, number of siblings, rural/urban residence and survey wave

power than the social class dimension. Secondly, the average chance of participating in higher education grows in each consecutive cohort. The odds of participating in tertiary education in the fifth cohort are between three and a half to four times higher ${ }^{4}$ than in the first (socialist) cohort, which is the baseline representing the conditions before the major expansion that started in the early 1990s (Table 2, columns 1 \& 3). Moreover, it is a conservative estimation because the participation of the youngest cohort is biased down due to differences in the age distribution of cohorts in the pooled dataset. Hence, an increase in the participation rate in higher education in Poland over the two following decades reflects a change in educational behavior, not mere compositional changes of social background characteristics.

Allowing changes in participation odds between cohorts to vary over social origin groups (Models \#2) informs about the dynamic of social inequality in access to tertiary education. I

\footnotetext{
$\overline{{ }^{4} \text { Differences between cohort effects }}$ in estimations with educational and social class origin are due to small sample differences
} 
start with the model for parental education (Table 2, column 4). Here, the interaction effects are not significant, indicating insignificant changes in relative odds between social origin groups despite the expansion of educational opportunity. Thus, regarding educational background, there is no evidence of inequality in access to tertiary education decreasing, or increasing following the expansion of study opportunities. In contrast, Model 2, for social class (Table 2, column 2), reveals important differences between social class origin groups. The main effect for the third cohort, which is now the conditional effect in the upper service class, decreases considerably and turns insignificant. Thus, in the first phase of the tertiary education expansion, the growth in the odds of enrollment among the most privileged group was very weak at best. A strong and positive interaction effect for the lower service class in the third cohort suggests that the rapid growth in the odds of participating in higher education in the first half of the 1990s, as indicated by Model 1 (Table 2, column 1), was driven mainly by this class. In turn, the odds of children from the upper service class participating in higher education grew strongly in the subsequent cohorts. Their relative chance of enrolling increases by the fifth cohort to four and a half times the pre-expansion level. The non-significant interaction effects for other classes point to the fact that the development dynamic there has not been sufficiently different from the highest class as to yield a significant estimate, given the sample size. It is important to note here, however, that the growth in participation chances has been, in fact, the highest in the lower service class. When this class serves as baseline, the model postestimation shows a significantly lower growth in chances for enrollment in the working class by the fourth cohort.

Because of the multiplicative character of interaction terms in a logit model, they are not always easy to interpret (Buis 2010). Therefore, in order to get a better understanding of the inequality dynamic, it is useful to look at the predicted probabilities of different social origin groups across cohorts participating in higher education. Figure 2 presents the estimations and their respective confidence intervals.

Children of tertiary-educated fathers were able to retain or even increase their advantage relative to other educational backgrounds as tertiary education expanded. Only after this group achieved participation rates of over $80 \%$ did children of upper secondaryeducated fathers start to reduce their distance. This development is highly congruent with the MMI thesis. In contrast, the relations between social classes developed in a manner that contradicts it. In the early phase of the expansion, the participation rates in the upper service class stagnated, so the lower service class caught up with the most privileged group. At that time, the working class also reduced their disadvantage. In the following cohorts, the chances of participation rose disproportionally strongly for the upper service class, and the cleavage between them and the working class widened again. Such a dynamic points to the exceptional phase of the early 1990s. It is plausible that at that time of mass privatization and lucrative business opportunities within the emerging private sector, the most privileged class of higher managers of state enterprises and party officials decided not to invest in education as a social reproduction strategy, but to engage directly in business instead. Importantly, the chances of students of an entrepreneurial background increased very fast in the later phases of expansion, and by the fifth cohort, they had reached participation rates equal to the service classes. At the end of the expansion phase, the opportunity structure regarding class background presented a dichotomy between the disadvantaged working class and the intermediate and service classes.

The data corroborates the adaptational lag hypothesis. Working-class children's odds of participating in higher education increased considerably only in the second and the third 

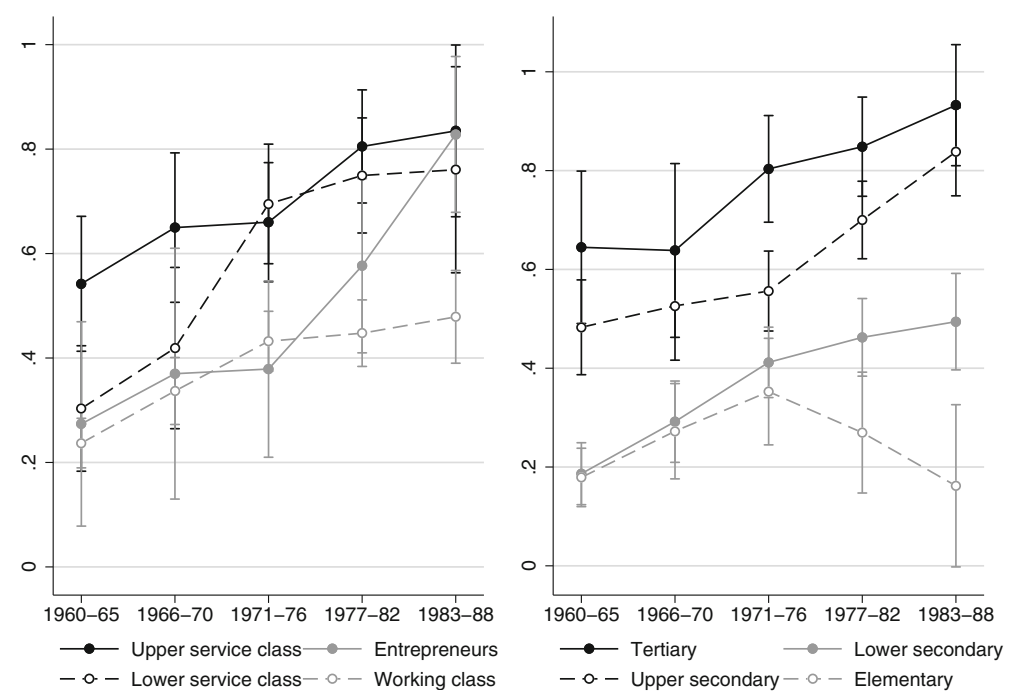

Fig. 2 Predicted probabilities of enrollment in higher education institution across cohorts and social origin groups

cohort, and then it almost stagnated at a low level in the following period despite the saturation or near saturation in the higher social classes. Whereas this initial increase can be attributed to the working class achieving the existing educational aspirations level that had been suppressed by reduced educational opportunities in the past, its subsequent stagnation may be an indication of them failing to adapt to the new opportunities. Similarly, the growth in participation rates in lower educational backgrounds is weak despite saturation levels being reached in the academic and upper secondary educational groups. In the most disadvantaged group, with elementary-educated fathers, the chances of participating actually decrease, which can be attributed to the changing composition of this group resulting from the educational expansion in the parental generation. All in all, the results indicate that even under the condition of saturation in higher social origin groups, the odds of individuals from lower social backgrounds participating in higher education may not rise owing to failing educational aspirations there. In such a case, the educational expansion comes to a halt, a situation that can indeed be observed in Poland.

Lastly, according to the expansion via marketization thesis, I expected to find stronger effects of social class than parental education on the odds of attending higher education. The data speak against this assumption. Overall, the predictive power of parental education is higher than that of parental social class. The model fit statistic for otherwise identical models (\#1 and \#2) is higher for the specification with education. Furthermore, the two social origin dimensions show different development patterns of their effect in the course of educational expansion. Educational inequality with respect to class declines, even if only in the upper part of the social structure. The lower service class and, somewhat later, also the entrepreneurial class reduce their distance to the most privileged group. In contrast, the difference in the probability of participating in higher education between children of tertiary-educated fathers and children with lower qualified fathers increases. Lastly, a model specification containing both dimensions of social background shows that across the whole sample social class effects are mediated via education (see Table A2 in the appendix). They become insignificant after controlling for the father's educational attainment. Still, there is an important gender dimension 
in the effect of class-lower class positions significantly disadvantage men, but not women (results not shown; available on request from the author). It seems, therefore, that throughout the expansion, money was not such an important barrier to participation as cultural capital in the form of parental education (Bourdieu and Passeron 1990; Jæger 2011; Roksa and Robinson 2017).

\section{Inequality within the higher education system}

I turn now to the question concerning the increased propensity of students of lower social origin to be enrolled in lower status educational programs as a concomitant of expansion in higher education. According to the diversion thesis, with a growing proportion of a birth cohort attending a given level of education, processes of internal stratification within this level occur, thus effectively maintaining educational inequality. In this paper, I use two indicators of diversion: being enrolled in a study program with a tuition fee, and attaining a more demanding master's degree compared to finishing tertiary education with only a bachelor's degree. Two binary logistic regression models predict the chances of a respective positive outcome regarding the social origin characteristics of students.

The columns 1 to 4 of Table 3 inform about the odds of having to pay for one's studies. We see that the average odds of being enrolled in a privately funded program do not increase as the expansion progresses. After the initial major rise in the early 1990s, the entry rates to paid programs of any kind remained largely stable. It is important to note, though, that given the relatively small sample size, changes in the magnitude of several percentage points do not yield a statistically significant effect.

There are substantial social class and parental education effects on the relative probability of being admitted to a study program with a tuition fee. Consistent with the expectation of the diversion thesis, lower social classes are less capable of securing their children a place on a more prestigious, full-time study program at a public higher education institution. For the children of the working class the odds of having to pay for their studies is almost two times larger than that of children of the upper service class. (Table 3, column 1). The case for the other dimension of social inequality - parental education - is much the same. Coming from an upper secondary-educated family increases the odds of being in a program with a tuition fee more than one and a half times, and a lower secondary background raises the odds more than two times (Table 3, column 3). The effect for children with only elementary-educated fathers is not significant in the sample in the proposed model specification. Because children of elementary-educated fathers reside mostly in rural areas and have a higher number of siblings, it is possible, however, that the effect is dragged down by the control variables. In the alternative specification, which controls neither for the place of residence nor for the number of siblings, the estimated effect is high and significant at the 0.05 level. Additionally, the category is much smaller in size than for the upper and lower secondary educated, which may lead to larger standard errors.

At the same time, there is little dynamic in the odds ratios between groups with different educational and class backgrounds. The coefficients for interaction terms (Table 3, columns 2 $\& 4$ ) are not significant, suggesting that inequality in access to more prestigious free-of-charge study programs is stable. It seems, therefore, that from the beginning of the $1990 \mathrm{~s}$, the marketdriven expansion of the tertiary sector created a secondary path to higher education attainment for lower educational backgrounds, thus first creating and then stabilizing inequality in this respect. In Model 2, with parental education (Table 3, column 4), the effects of parental 


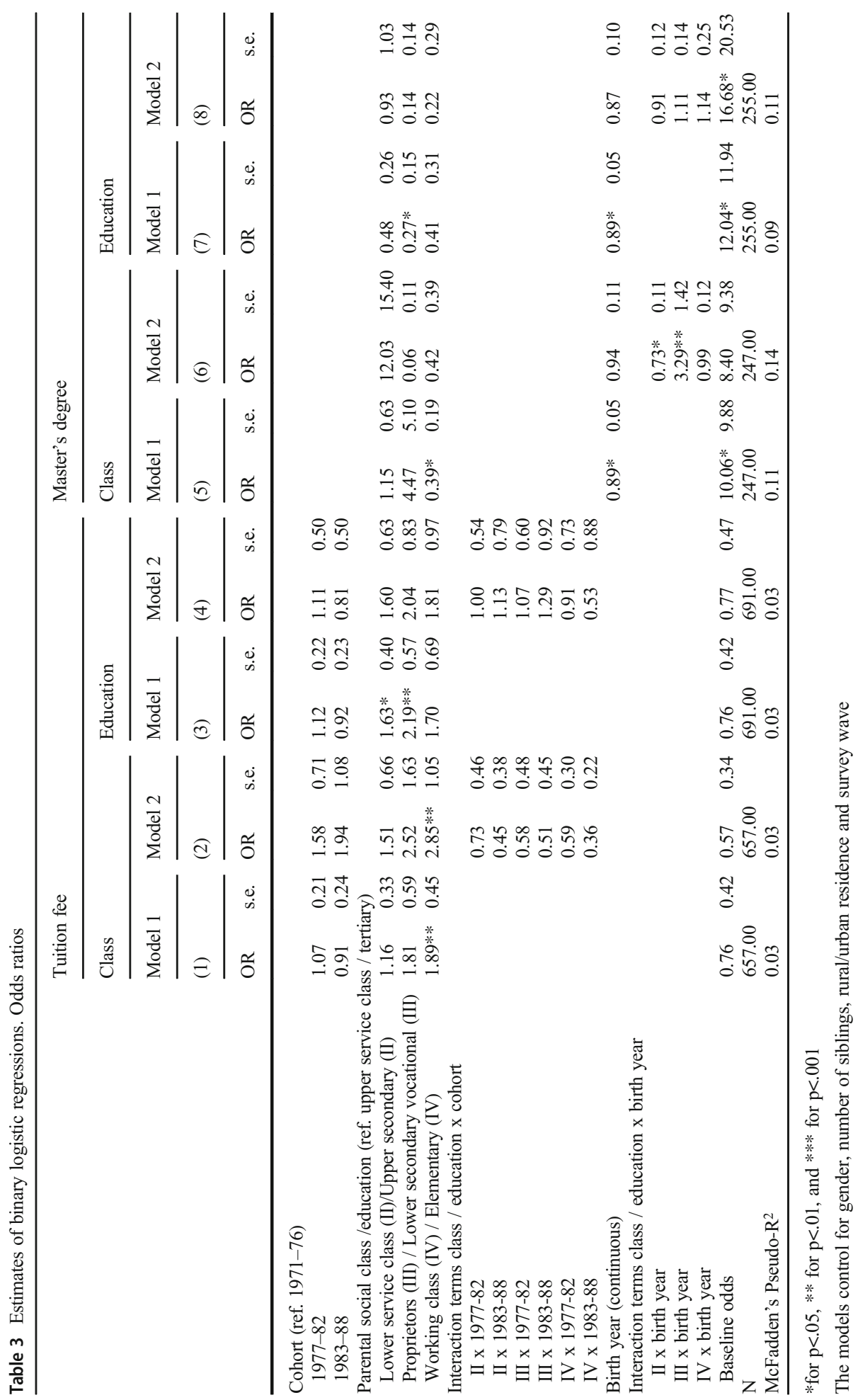


educational background turn insignificant. Obviously, the small sample size makes it hard to reach standard significance levels of differences between social origin groups within cohorts. There is little difference in coefficient values compared to Model 1 (column 3), however, which suggests that the effect of parental education is stable across cohorts and significant across the whole sample (as indicated by Model 1).

The second indicator for diversion adopted in this study was the choice to quit after obtaining a bachelor's degree or to continue studying and achieve a master's degree. The columns 5 to 8 in Table 3 summarize the binary logistic estimation results. Lower educational and class backgrounds are disadvantaged when it comes to attaining a master's degree. On average, the odds of children with a working-class background ending their studies with a master's degree is only $39 \%$ of the reference category upper service class (Table 3, column 5). Having a father educated at the lower secondary level decreases the odds more than three times compared with the reference category of children of a tertiary-educated father (Table 3, column 7). The effects for children of only elementary-educated fathers, as well as for children from an upper secondary educational background, are not significant in my sample. Due to the small sample size, even effects of considerable size may not achieve standard significance levels; therefore, further analysis of larger datasets is necessary in order to achieve a reliable picture of the amount of disadvantage. Nevertheless, the magnitude of the estimated effects suggests that it is non-negligible. The model also points at a general trend of the decreasing prevalence of a master's degree. The odds of attaining one fall in each consecutive birth cohort to ca. $90 \%$ of the previous year, on average. It is a clear effect of the development of the private sector in higher education, which offered mainly lower-level degrees only. It is also the result of the Bologna Process, which contributed to a further spread of bachelor's degrees within the Polish higher education system by introducing them at state universities (Kwiek 2014).

According to the model specification with interaction terms (Table 3, column 8), the propensity to finish education at the master's level decreases at the same pace in each educational background category, thus resulting in stable social inequality in this respect. In contrast, interaction terms with social class reveal differences in development patterns between classes (Table 3, column 6). With the expansion of tertiary education, the odds of achieving a master's degree decrease for the lower service class more strongly than for the reference category upper service class, which may be interpreted as an increasing diversion of lower service class students into obtaining only a bachelor's degree. In contrast, entrepreneurial background increases the chances for the higher-level degree, thus compensating for the initial disadvantage of this class. This high dynamic may also explain why the average effects for both classes are insignificant in the model without interaction terms. The odds of obtaining a master's degree are stable in the upper service class and the working class, preserving the relative disadvantage of the latter group.

Figures 3 and 4 provide a graphical summary of the obtained results with respect to the two indicators of diversion in the higher education sector in a probability metric.

To sum up, expansion via marketization has created second-tier educational opportunities, which allowed lower-education and lower-class backgrounds to enter tertiarylevel education, but it resulted in internal inequality. Children of lower social class and educational backgrounds are less likely to study at a public higher education institution 

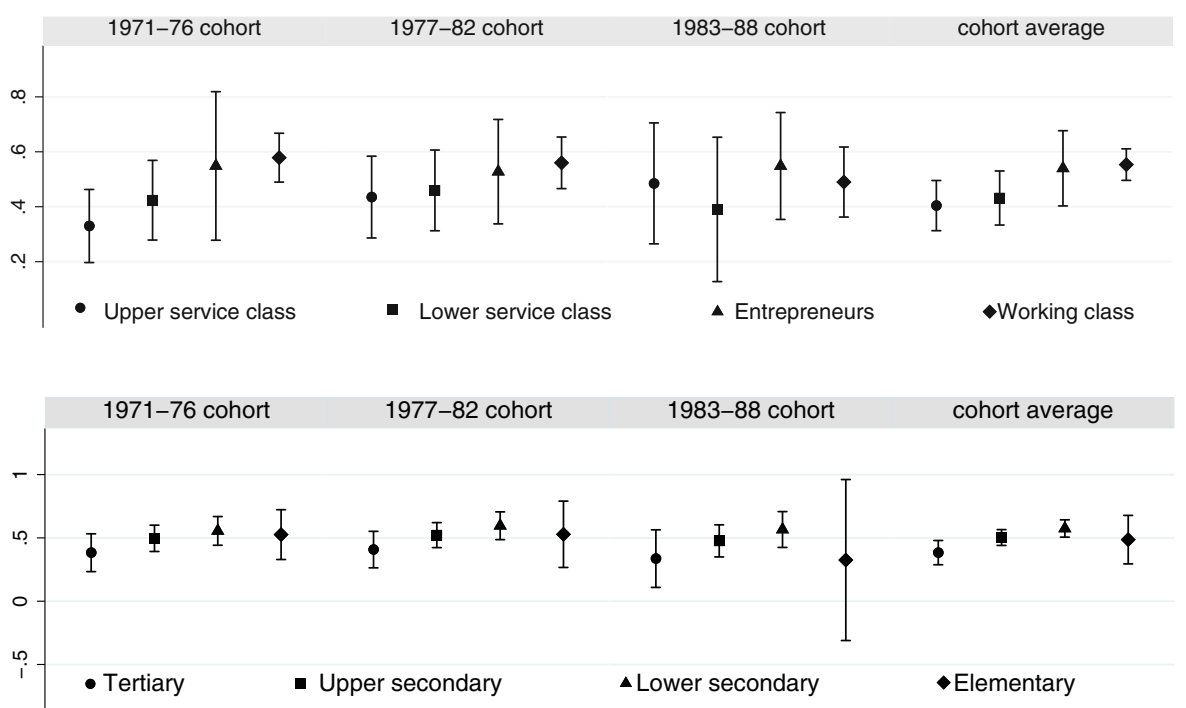

Fig. 3 Predicted probabilities of paying a tuition fee across cohorts and social origin groups. Upper panel: father's social class. Lower panel: father's education

in more prestigious tuition-free programs and are less likely to achieve a master's degree. Importantly, the relative disadvantage of working class and lower secondary educational backgrounds does not increase across birth cohorts, possibly indicating stronger selection mechanisms to any type of tertiary education there than in the lower service class and upper secondary education background.
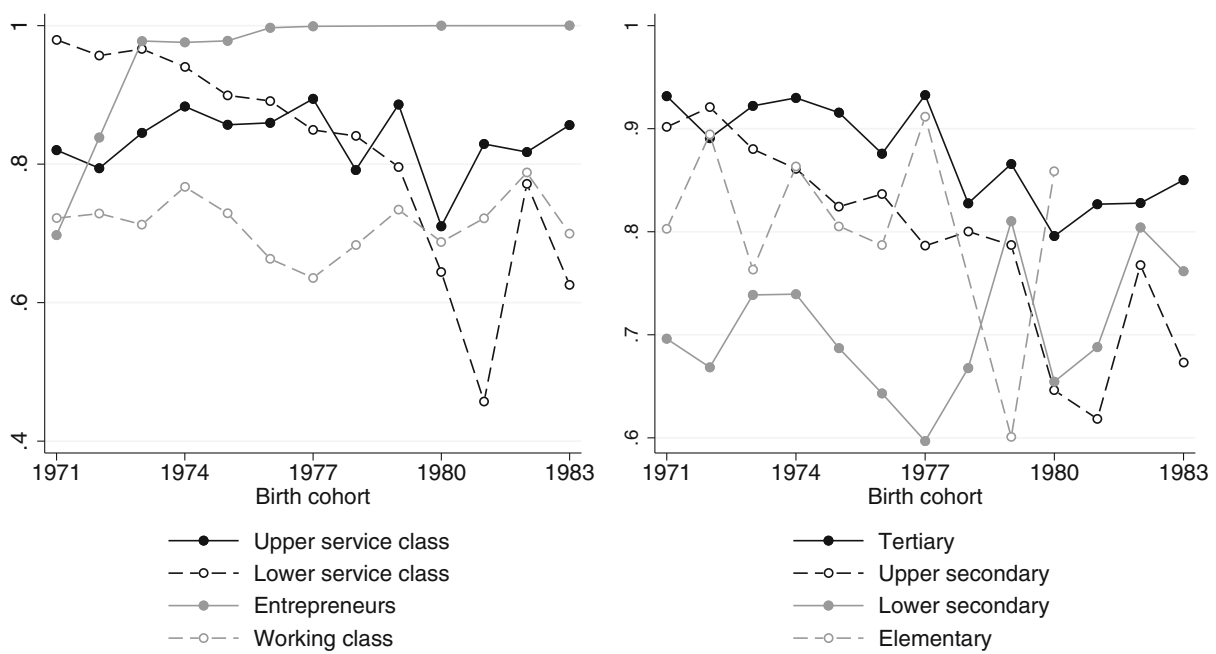

Fig. 4 Predicted probabilities of achieving a master's degree across time and social origin groups. Left panel: father's social class. Right panel: father's education 


\section{Conclusions}

The major goal of this paper was to test the Maximally Maintained Inequality and the Effectively Maintained Inequality theses on the case of a post-socialist society with very rapid growth in higher education opportunities, which was mainly achieved by the marketization of this sector. According to the analysis presented in this paper, the Polish case corroborates the EMI thesis. There is indeed evidence of a diversion of lower social origin students into less prestigious and lower quality educational programs offered mostly by the private tertiary education sector, which emerged and grew rapidly from the early 1990s. Such a high pace of expansion via marketization was possible because there was a high amount of unmet demand for tertiary education in Polish society. On the one hand, privately funded tertiary education was fueled by this demand. On the other, it was made possible by academic staff's demand for additional sources of income in the emerging market economy, owing to comparatively low remuneration in public higher education institutions. Both the emerging private providers as well as tuition-fee-based part-time programs at public universities provided opportunities for extra pay. As a result, a second-tier tertiary education offer emerged, which has absorbed students from less privileged social backgrounds. The accessibility for the lower social origin groups increased, but at the cost of diversion.

The MMI thesis, in contrast, does not find unequivocal support in the analysis, showing that there are important limits to its universality as a macro-level theory, and that they lie possibly in the issue of preferences. According to the statistical model, which allows the social class effects on the chances of participating in higher education to vary between cohorts, it was the lower service class who benefitted, mostly in the early phase of expansion. Even though the highest class was far from the saturation point at that time, the odds of this social origin group participating in higher education increased at a below-average rate. As a result, the distance between the two classes vanished much earlier than the MMI argument would predict. Furthermore, in the younger cohorts, there is no sign of rising participation rates in lower social origin groups despite higher social strata having reached a state of saturation.

The empirical evidence can only be explained if the theoretical argument is extended to account for changing educational preferences. Such an extension was formally proposed by Breen and Goldthorpe (1997) in their RAT model of educational decisions. The authors show that (a) persistent educational inequality is conditional upon differences between classes in their educational preferences, which in turn arise from their different paths to status reproduction; and that (b) the educational equalization process greatly depends on the evolution of the educational preferences of underprivileged classes for higher levels of schooling (see also most recent evidence from China, Liu 2019). With respect to (a), the higher class will invest in tertiary education because it gives them the best chances for social status reproduction. However, when alternative channels to achieve a preferred social position emerge, their educational motivation may change, reflecting opportunities in other domains. Such a situation might indeed have occurred at the beginning of the 1990s in Poland, a time of rapid privatization of state enterprises and emerging business opportunities, for which access to social networks and relevant information (greatly monopolized by the nomenklatura) was of crucial importance. This exceptional phase of an emerging market economy resulting in a temporal change in educational preferences of the most privileged social group was of limited duration, however. Therefore, in the following cohorts, we observe rapidly rising participation rates in the highest class, compensating for the stagnation in the early 1990 s. 
Regarding (b), inequality in educational attainment will decrease under the condition of saturation in higher social backgrounds, on condition that there is an unmet demand for education in the lower classes. If, however, the educational aspirations of the underprivileged do not change, their level of participation will not increase, and expansion will come to a halt. Because of a general trend of rising returns to education, Breen and Goldthorpe assume increasing educational motivation also in lower social status groups. However, in a situation of the rapid growth of study opportunities, its pace may be higher than the speed of attitude change. In such a case, in congruence with the adaptational lag hypothesis formulated in this paper, the expansion of higher education would unfold as an unsteady process, with an initial expansion, then a period of stability (with higher social strata having reached saturation and lower social status groups still clinging to the "old" level of educational aspirations) and then again an expansion phase. Such a three-phase development pattern has, in fact, been observed in Great Britain. By the end of my observation window, Polish data show the beginning of a stability phase in participation rates. It is yet to be seen if this phase of stability will be followed by a second expansion.

Most interestingly, when social origin is defined by parental education rather than social class, the development in participation rates and odds ratios between different educational origin groups is largely congruent with the MMI thesis. Thus, the data corroborate earlier findings of a differentiated effect of the dimensions of social origin on educational inequality. While the new business elite may bypass educational credentials on their way to achieving the highest social positions, the intelligentsia remains firmly attached to university education as an indispensable element of their social status.

Lastly, it is important to address the limitations of the present study. Focusing only on one country, and, even more so, on a country undergoing massive changes in its major systems of social coordination, clearly does not allow us to draw causal inferences about the relationship between educational expansion and inequality. Rather, the main contribution of the paper is to turn attention to the micro-level mechanisms that underly this relationship, which become manifest in the specific historical context of the study. More precisely, I highlight the necessity to view preferences of social strata driving their educational behavior as an empirical matter and account for their potential dynamic, rather than treat them as fixed. Secondly, the paper suffers from data limitations. The sample sizes are sometimes too small to allow for a significant estimate of group-level differences. The problem pertains mostly to predictions concerning the attainment of a master's degree versus a bachelor's degree. Taking into consideration the small number of observations, the results of this model should be treated with caution. Furthermore, the category of children with only elementary-educated fathers massively decreases in size from cohort to cohort, owing to educational expansion at the secondary level in the parents' generation. Estimates for this group in the younger cohorts, therefore, lack desirable precision.

Acknowledgements This work was supported by the German Academic Exchange Service (DAAD) under the Postdoctoral Research Fellowship Scheme P.R.I.M.E.

For comments on earlier versions of the paper, I am grateful to colleagues from the Institute of Sociology, Chair for Social Structure Analysis of the University of Halle-Wittenberg, as well as colleagues from the Department of Macroeconomics of the University of Lodz. Moreover, I thank two anonymous reviewers for their valuable comments. 
Open Access This article is licensed under a Creative Commons Attribution 4.0 International License, which permits use, sharing, adaptation, distribution and reproduction in any medium or format, as long as you give appropriate credit to the original author(s) and the source, provide a link to the Creative Commons licence, and indicate if changes were made. The images or other third party material in this article are included in the article's Creative Commons licence, unless indicated otherwise in a credit line to the material. If material is not included in the article's Creative Commons licence and your intended use is not permitted by statutory regulation or exceeds the permitted use, you will need to obtain permission directly from the copyright holder. To view a copy of this licence, visit http://creativecommons.org/licenses/by/4.0/.

\section{References}

Altbach, P., Reisberg, L., \& Rumbley, L. (2009). Trends in global higher education: Tracking an academic revolution: A report. UNESCO 2009 world conference on higher education. Paris: UNESCO http://lst-iiep. iiep-unesco.org/cgi-bin/wwwi32.exe/[in=epidoc1.in]/?t2000=026771/(100.

Antonowicz, D., Kwiek, M., \& Westerheijden, D. F. (2017). The government response to the private sector expansion in Poland. In H. de Boer, J. File, J. Huisman, M. Seeber, M. Vukasovic, \& D. F. Westerheijden (Eds.), Policy analysis of structural reforms in higher education: Processes and outcomes (pp. 119-138). Cham: Springer International Publishing.

Arum, R., Gamoran, A., \& Shavit, Y. (2007). More inclusion than diversion: Expansion, differentiation, and market structure in higher education. In Y. Shavit (Ed.), Stratification in higher education: A comparative study (pp. 1-38, studies in social inequality). Stanford: Stanford Univ. Press.

Ayalon, H., \& Mcdossi, O. (2019). Economic achievements of nonacademic parents and patterns of enrollment in higher education of their children: The case of Israel. Higher Education, 77(1), 135-153.

Ayalon, H., \& Shavit, Y. (2004). Educational reforms and inequalities in Israel: The MMI hypothesis revisited. Sociology of Education, 77(2), 103-120.

Beller, E., \& Hout, M. (2006). Welfare states and social mobility: How educational and social policy may affect cross-national differences in the association between occupational origins and destinations. Research in Social Stratification and Mobility, 24(4), 353-365.

Bloch, R., \& Mitterle, A. (2017). On stratification in changing higher education: The "analysis of status" revisited. Higher Education, 73(6), 929-946.

Blossfeld, P. N., Blossfeld, G. J., \& Blossfeld, H.-P. (2017). The speed of educational expansion and changes in inequality of educational opportunity. In T. Eckert \& B. Gniewosz (Eds.), Bildungsgerechtigkeit (pp. 7792). Wiesbaden: Springer Fachmedien Wiesbaden.

Boliver, V. (2011). Expansion, differentiation, and the persistence of social class inequalities in British higher education. Higher Education, 61(3), 229-242.

Bourdieu, P., \& Passeron, J.-C. (1990). Reproduction in education, society and culture. London: Sage.

Breen, R. (2004). Social mobility in Europe. Oxford [u.a.]: Oxford Univ. Press.

Breen, R., \& Goldthorpe, J. H. (1997). Explaining educational differentials: Towards a formal rational action theory. Rationality and Society, 9(3), 275-305.

Buis, M. L. (2010). Stata tip 87: Interpretation of interactions in nonlinear models. The Stata Journal, 10(2), 305308.

Bukodi, E. B, \& Goldthorpe, J. H. (2012). Decomposing 'Social Origins': The Effects of Parents' Class, Status, and Education on the Educational Attainment of Their Children (Vol. 29.

Cichomski, B., Jerzyński, T., \& Zieliński, M. (2013). Polskie Generalne Sondaże Społeczne: skumulowany komputerowy zbiór danych 1992-2010 [Polish General Social Surveys: pooled digital dataset 1992-2010]. Warszawa: Instytut Studiów Społecznych, Uniwersytet Warszawski.

Cichomski, B., \& Sawiński, Z. (1995). Polski Generalny Sondaż Społeczny. Założenia i realizacja programu [Polish general social survey. Background and realization]. ASK: Research and Methods, 1(1), 101-109.

Czarnecki, K. (2018). Less inequality through universal access? Socioeconomic background of tertiary entrants in Australia after the expansion of university participation. Higher Education, 76(3), 501-518.

DiMaggio, P. (1982). Cultural capital and school success: The impact of status culture participation on the grades of U.S. high school students. American Sociological Review, 47(2), 189-201.

Długosz, P. (2013). Sytuacja absolwentów studiów wyższych na rynku pracy a jakość wykształcenia. Nierówności społeczne a wzrost gospodarczy, 33, 43-54.

Domański, H. (2011). Rise of meritocracy in Poland: 1982-2008. European Sociological Review, 27(3), 400411.

Domański, H., Mach, B. W., \& Przybysz, D. (2008). Pochodzenie społeczne - wykształcenie - zawód: ruchliwość społeczna w Polsce w latach 1982-2006 [Social Background - Education - Occupation: Social 
Mobility in Poland 1982-2006]. In H. Domański (Ed.), Zmiany stratyfikacji spolecznej w Polsce [changes in social stratification in Poland] (pp. 97-132). Warszawa: IFiS PAN.

Domański, H., \& Przybysz, D. (2003). Analiza przydatności schematu EGP jako wskaźnika pozycji społecznej. ASK: Research and Methods, 2003(12), 85-116.

Duta, A., An, B., \& Iannelli, C. (2018). Social origins, academic strength of school curriculum and access to selective higher education institutions: Evidence from Scotland and the USA. Higher Education, 75(5), 769 784.

Erikson, R., Goldthorpe, J. H., \& Portocarero, L. (1979). Intergenerational class mobility in three Western European societies: England. France and Sweden. British Journal of Sociology, 30.

European Commission (2018). Access to universities in the EU: a regional and territorial analysis (Regional Focus): European Commission.

GUS (Główny Urząd Statystyczny [Central Statistical Office]) (1981-2016). Szkoły wyższe i ich finanse [higher education institutions and their finances]. Warszawa: GUS.

Hanushek, E. A. (1992). The trade-off between child quantity and quality. Journal of Political Economy, 100(1), 84-117.

Hendrickx, J. (2002). ISKO: Stata module to recode 4 digit ISCO-88 occupational codes. Statistical Software Components: Boston College Department of Economics.

Herbst, M., \& Rok, J. (2014). Equity in an educational boom: Lessons from the expansion and marketisation of tertiary schooling in Poland. European Journal of Education, 49(3), 435-450.

Hout, M. (2006). Maximally maintained inequality and essentially maintained inequality. Crossnational comparisons. Sociological Theory and Methods, 21(2), 237-252.

Hout, M. (2007). Maximally maintained inequality revisited. Irish educational mobility in comparative perspective. In M. N. Phadraig, \& E. Hilliard (Eds.), Changing Ireland, 1989-2003. Berkeley: Survey Research Center.

Jablecka, J. (2007). Legitimation of nonpublic higher education in Poland. In Private higher education in postcommunist Europe: In search of legitimacy (pp. 179-199). New York: Palgrave Macmillan US.

Jæger, M. M. (2011). Does cultural capital really affect academic achievement? New evidence from combined sibling and panel data. Sociology of Education, 84(4), 281-298.

Jeruszka, U. (2011). Efektywność kształcenia w szkołach wyższych. Polityka Społeczna, 2011(1), 1-7.

Kogan, I., Gebel, M., \& Noelke, C. (2013). Educational systems and inequalities in educational attainment in central and eastern european countries. Studies of Transition States and Societies, [S.l.], 4(1).

Konstantinovskiy, D. L. (2017). Expansion of higher education and consequences for social inequality (the case of Russia). Higher Education, 74(2), 201-220.

Kwiek, M. (2009). The two decades of privatization of Polish higher education. In J. Knight (Ed.), Financing access and equity in higher education (Vol. 17, pp. 149-167, global perspectives on higher education). Rotterdam: Sense Publishers.

Kwiek, M. (2011). Creeping marketization: Where Polish public and private higher education sectors meet. In R. Brown (Ed.), Higher education and the market (pp. 135-145). New York: Routledge.

Kwiek, M. (2014). Social perceptions versus economic returns of the higher education: The Bologna process in Poland. In T. Kozma, A. Óhidy, M. Rébay, \& É. Szolár (Eds.), The Bologna process in central and Eastern Europe (pp. 147-182). Wiesbaden: Springer VS.

Kwiek, M. (2015). European universities and educational and occupational intergenerational social mobility. In H.-U. Otto, R. Atzmüller, T. Berthet, \& L. Bifulco (Eds.), Facing trajectories from school to work (pp. 87111). Cham Heidelberg New York Dordrecht London: Springer International Publishing.

Kwiek, M. (2016). From privatization (of the expansion era) to De-privatization (of the contraction era): A National Counter-Trend in a global context. In S. Slaughter \& B. J. Taylor (Eds.), Higher education, stratification, and workforce development: Competitive advantage in Europe, the US, and Canada (pp. 311329). Cham: Springer International Publishing.

Kwiek, M. (2018). Private higher education in developed countries. In Encyclopedia of international higher education systems and institutions (pp. 1-9). Dordrecht: Springer Netherlands.

Liu, Y. (2019). Choices, risks and rational conformity: Extending Boudon's positional theory to understand higher education choices in contemporary China. Higher Education, 77(3), 525-540.

Lucas, S. (2001). Effectively maintained inequality: Education transitions, track mobility, and social background effects. American Journal of Sociology, 106(6), 1642-1690.

Marginson, S. (2016). The worldwide trend to high participation higher education: Dynamics of social stratification in inclusive systems. Higher Education, 72(4), 413-434.

Mood, C. (2010). Logistic regression: Why we cannot do what we think we can do, and what we can do about it. European Sociological Review, 26(1), 67-82.

Myck, M., \& Najsztub, M. (2016). Distributional consequences of tax and benefit policies in Poland: 2005-2014. CenEA Working Paper Series, 2016(2). 
Nee, V. (1989). A theory of market transition: From redistribution to markets in state socialism. American Sociological Review, 54(5), 663-681.

Nee, V., \& Cao, Y. (2002). Postsocialist inequalities: The causes of continuity and discontinuity. Research in Social Stratification and Mobility, 19, 3-39.

Noelke, C., Kogan, I., \& Gebel, M. (2012). Educational systems and inequalities in educational attainment in central and eastern European countries. Studies of Transition States and Societies, 4(1), 69-83.

OECD. (2007). Higher education and regions: Globally competitive, locally engaged. Paris: OECD Publishing.

Pinheiro, R., \& Antonowicz, D. (2015). Opening the gates or coping with the flow? Governing access to higher education in northern and Central Europe. Higher Education, 70(3), 299-313.

Piróg, D. (2013). Absolwenci szkół wyższych na rynku pracy w warunkach kryzysu. Przedsiębiorczość Edukacja, 9, 302-316.

Raftery, A. E., \& Hout, M. (1993). Maximally maintained inequality: Expansion, reform, and opportunity in Irish education, 1921-75. Sociology of Education, 66(1), 41-62.

Rahona López, M. (2009). Equality of opportunities in Spanish higher education. Higher Education, 58(3), 285306.

Roksa, J., \& Robinson, K. J. (2017). Cultural capital and habitus in context: The importance of high school college-going culture. British Journal of Sociology of Education, 38(8), 1230-1244.

Sawiński, Z. (2018). Social change, educational expansion, and inequality in access to education. In I. TomescuDubrow, K. M. Słomczyński, H. Domański, J. K. Dubrow, Z. Sawiński, \& D. Przybysz (Eds.), Dynamics of class and stratification in Poland (pp. 111-134). Budapest: Central European University Press.

Schendel, R., \& McCowan, T. (2016). Expanding higher education systems in low- and middle-income countries: The challenges of equity and quality. Higher Education, 72(4), 407-411.

Schofer, E., \& Meyer, J. W. (2005). The worldwide expansion of higher education in the twentieth century. American Sociological Review, 70(6), 898-920.

Shavit, Y., \& Blossfeld, H.-P. (1993). Persistent inequality: Changing educational attainment in thirteen countries (social inequality series). Boulder: Westview Press.

Słomczyński, K. M., \& Shabad, G. (1996). Systemic transformation and the salience of class structure in east Central Europe. East European Politics and Societies, 11(1), 155-189.

Staniszkis, J. (1990). "political capitalism" in Poland. East European Politics and Societies, 5(1), $127-141$.

Trow, M. C. (1970). Reflections on the transition from mass to universal higher education. Daedalus, 99(1), 142.

Valero, A., \& Van Reenen, J. (2019). The economic impact of universities: Evidence from across the globe. Economics of Education Review, 68, 53-67.

Walters, P. B. (2000). The limits of growth. In M. T. Hallinan (Ed.), Handbook of the sociology of education (pp. 241-261). Boston: Springer US.

Wasielewski, K. (2015). Funkcje szkolnictwa wyższego dla obszarów wiejskich - wybrane zagadnienia z perspektywy socjologa [functions of higher education for rural areas - selected issues from a sociological point of view]. Studia Obszarów Wiejskich [Rural Studies], 40, 21-33.

Welch, A. R. (2007). Blurred vision?: Public and private higher education in Indonesia. Higher Education, 54(5), 665-687.

Wu, X. (2010). Economic transition, school expansion and educational inequality in China, 1990-2000. Research in Social Stratification and Mobility, 28(1), 91-108.

Zając, T., Jasiński, M.A, \& Bożykowski, M. (2017). Does It Pay to Be a STEM Graduate? Evidence from the Polish Graduate Tracking System. Research \& Occasional Paper Series: CSHE.13.17.

Publisher's note Springer Nature remains neutral with regard to jurisdictional claims in published maps and institutional affiliations. 